\title{
COMPARISON OF METHODS FOR ESTIMATING THE OPTIMUM PLOT SIZE FOR PEARL MILLET, SLENDER LEAF RATTLEBOX, AND SHOWY RATTLEBOX ${ }^{1}$
}

\author{
ALBERTO CARGNELUTTI FILHO ${ }^{2 *}$, MARCOS VINÍCIUS LOREGIAN ${ }^{3}$, VALÉRIA ESCAIO BUBANS $^{3}$, \\ FELIPE MANFIO SOMAVILLA ${ }^{4}$, SAMANTA LUIZA DA COSTA ${ }^{4}$
}

\begin{abstract}
This study aimed to compare three methods of estimating the optimum plot size to evaluate the fresh matter productivity of pearl millet (Pennisetum glaucum L.), slender leaf rattlebox (Crotalaria ochroleuca), and showy rattlebox (Crotalaria spectabilis). Twenty-seven uniformity trials were carried out with pearl millet, slender leaf rattlebox, and showy rattlebox cultivated alone and intercropped. Fresh matter productivity was evaluated in 972 basic experimental units (BEU) of $1 \mathrm{~m} \times 1 \mathrm{~m}$ (36 BEU per trial). The optimum plot size was determined using the methods modified maximum curvature, linear response with plateau model, and quadratic response with plateau model. The optimum plot size differs between methods and decreases in the following order: quadratic response with plateau model $\left(9.94 \mathrm{~m}^{2}\right)$, linear response with plateau model $\left(7.41 \mathrm{~m}^{2}\right)$, and modified maximum curvature $\left(3.49 \mathrm{~m}^{2}\right)$. The optimum plot size to evaluate the fresh matter productivity of pearl millet, slender leaf rattlebox, and showy rattlebox cultivated alone or intercropped is $7.41 \mathrm{~m}^{2}$. This size could be used as a reference for future experiments.
\end{abstract}

Keywords: Uniformity trial. Intercropping. Estimation models.

\section{COMPARAÇÃO DE MÉTODOS DE ESTIMAÇÃO DO TAMANHO ÓTIMO DE PARCELA EM MILHETO, CROTALÁRIA OCHROLEUCA E CROTALÁRIA SPECTABILIS}

RESUMO - O objetivo deste trabalho foi comparar três métodos de estimação do tamanho ótimo de parcela para avaliar a produtividade de matéria fresca de milheto (Pennisetum glaucum L.), crotalária ochroleuca (Crotalaria ochroleuca) e crotalária spectabilis (Crotalaria spectabilis). Foram conduzidos 27 ensaios de uniformidade com milheto, crotalária ochroleuca e crotalária spectabilis, em cultivo solteiro e em consórcio. Foi avaliada a produtividade de matéria fresca em 972 unidades experimentais básicas (UEB) de $1 \mathrm{~m} \times 1 \mathrm{~m}$ (36 UEB por ensaio). Foi determinado o tamanho ótimo de parcela por meio dos métodos da curvatura máxima modificado, do modelo linear de resposta com platô e do modelo quadrático de resposta com platô. O tamanho ótimo de parcela difere entre os métodos e decresce na seguinte ordem: modelo quadrático de resposta com platô $\left(9,94 \mathrm{~m}^{2}\right)$, modelo linear de resposta com platô $\left(7,41 \mathrm{~m}^{2}\right) \mathrm{e}$ curvatura máxima modificado $\left(3,49 \mathrm{~m}^{2}\right)$. O tamanho ótimo de parcela para avaliar a produtividade de matéria fresca de milheto, crotalária ochroleuca e crotalária spectabilis, em cultivo solteiro ou em consórcio é de 7,41 $\mathrm{m}^{2}$. Esse tamanho pode ser utilizado como referência para futuros experimentos.

Palavras-chave: Ensaio de uniformidade. Consorciação. Modelos de estimação. 


\section{INTRODUCTION}

Soil cover species, such as pearl millet (Pennisetum glaucum L.), slender leaf rattlebox (Crotalaria ochroleuca), and showy rattlebox (Crotalaria spectabilis) have been studied regarding different aspects, such as the soil cover rate, decomposition rate, nutrient content, and phytomass production (PASSOS et al., 2017; FERREIRA et al., 2019; PFÜLLER et al., 2019). Also, the effects on soil chemical and physical properties (PASSOS et al., 2017; SOUSA et al., 2017; ASCARI et al., 2020), soybean nematodes (DEBIASI et al., 2016), hence soybean and corn productivity (DEBIASI et al., 2016; ASCARI et al., 2020) have been investigated.

These experiments were carried out in plots of $12 \mathrm{~m}^{2}$ (PFÜLLER et al., 2019), $24 \mathrm{~m}^{2}$ (FERREIRA et al., 2019), $25 \mathrm{~m}^{2}$ (ASCARI et al., 2020), $50 \mathrm{~m}^{2}$ (PASSOS et al., 2017), $60 \mathrm{~m}^{2}$ (DEBIASI et al., 2016), and $150 \mathrm{~m}^{2}$ (SOUSA et al., 2017). However, the criteria used to define the plot size were not mentioned.

An important aspect when planning the experiment for a given crop is to define the optimum plot size to minimize the experimental error and, consequently, increase the precision of inferences. This size can be calculated using data from uniformity trials (blank experiments) of this same crop by different methods. Plot size has been investigated in the common cultivar of pearl millet (Pennisetum glaucum L.) (BURIN et al., 2015, 2016) and sunn hemp (Crotalaria juncea L.) (FACCO et al., 2017) using the maximum curvature of the model of the coefficient of variation (PARANAÍBA; FERREIRA; MORAIS, 2009), and in C. juncea (FACCO et al., 2018) using the modified maximum curvature method (MEIER; LESSMAN, 1971).

Comparative studies with the methods modified maximum curvature (MMC) (MEIER; LESSMAN, 1971), linear response with plateau model (LRP) (PARANAÍBA; FERREIRA; MORAIS, 2009), and quadratic response with plateau model (QRP) (PEIXOTO; FARIA; MORAIS, 2011) have been carried out with rice (PARANAIIBA; FERREIRA; MORAIS, 2009), wheat, and cassava (PARANAÍBA; MORAIS; FERREIRA, 2009), passion fruit (PEIXOTO; FARIA; MORAIS, 2011), papaya (BRITO et al., 2012), and forage palm (GUIMARÃES et al., 2019), showing different results between methods.

Uniformity trials allow planning different plot sizes (X) by grouping adjacent basic experimental units $(\mathrm{BEU})$ and estimating the coefficient of variation $\left(\mathrm{CV}_{(\mathrm{X})}\right)$ between $\mathrm{BEU}$. The values of $\mathrm{CV}_{(\mathrm{X})}$ and $\mathrm{X}$ can be related using the MMC, LRP, and QRP methods to determine the optimum plot size (Xo) and the coefficient of variation in the optimum plot size $\left(\mathrm{CV}_{\mathrm{Xo}}\right)$.

Uniformity trials carried out with different soil cover species cultivated alone or intercropped and the data set analysis by different methods may provide useful information to be used as a reference in the design of experiments, aiming at higher experimental precision.

Therefore, this study aimed to compare three methods of estimating the optimum plot size to evaluate the fresh matter productivity of pearl millet (Pennisetum glaucum L.), slender leaf rattlebox (Crotalaria ochroleuca), and showy rattlebox (Crotalaria spectabilis) cultivated alone or intercropped.

\section{MATERIAL AND METHODS}

Twenty-seven uniformity trials with pearl millet (Pennisetum glaucum L.) of the cultivar BRS 1501 (M), slender leaf rattlebox (Crotalaria ochroleuca) of the common cultivar (CO), and showy rattlebox (Crotalaria spectabilis) (CS) were conducted in an experimental area located at the geographic coordinates $29^{\circ} 42^{\prime} \mathrm{S}$ and $53^{\circ}$ $49^{\prime} \mathrm{W}$ and $95 \mathrm{~m}$ of altitude. The local climate is Cfa, according to the Köppen classification, that is, a humid subtropical climate with hot summers and no dry season (ALVARES et al., 2013). The soil of the area is classified as an Arenic Dystrophic Red Argisol (SANTOS et al., 2018).

Three uniformity trials (replications) were conducted for each of the following nine compositions with the respective sowing densities in parentheses: $100 \% \mathrm{M}\left(25 \mathrm{~kg} \mathrm{ha}^{-1}\right), 75 \% \mathrm{M}\left(18.75 \mathrm{~kg} \mathrm{ha}^{-1}\right)+25 \% \mathrm{CO}$ (4.6875 $\left.\mathrm{kg} \mathrm{ha}^{-1}\right), 50 \% \mathrm{M}\left(12.5 \mathrm{~kg} \mathrm{ha}^{-1}\right)+50 \% \mathrm{CO}$ $\left(9.375 \mathrm{~kg} \mathrm{ha}^{-1}\right), 25 \% \mathrm{M}\left(6.25 \mathrm{~kg} \mathrm{ha}^{-1}\right)+75 \% \mathrm{CO}$ $\left(14.0625 \mathrm{~kg} \mathrm{ha}^{-1}\right), 100 \% \mathrm{CO}\left(18.75 \mathrm{~kg} \mathrm{ha}^{-1}\right), 75 \% \mathrm{M}$ $\left(18.75 \mathrm{~kg} \mathrm{ha}^{-1}\right)+25 \% \mathrm{CS}\left(4.6875 \mathrm{~kg} \mathrm{ha}^{-1}\right), 50 \% \mathrm{M}$ $\left(12.5 \mathrm{~kg} \mathrm{ha}^{-1}\right)+50 \% \mathrm{CS}\left(9.375 \mathrm{~kg} \mathrm{ha}^{-1}\right), 25 \% \mathrm{M}$ $\left(6.25 \mathrm{~kg} \mathrm{ha}^{-1}\right)+75 \% \mathrm{CS}\left(14.0625 \mathrm{~kg} \mathrm{ha}^{-1}\right)$, and $100 \%$ $\mathrm{CS}\left(18.75 \mathrm{~kg} \mathrm{ha}^{-1}\right)$. The base fertilization was carried out on November 13, 2019, using $20 \mathrm{~kg} \mathrm{ha}^{-1}$ of N, $80 \mathrm{~kg} \mathrm{ha}^{-1}$ of $\mathrm{P}_{2} \mathrm{O}_{5}$, and $80 \mathrm{~kg} \mathrm{ha}^{-1}$ of $\mathrm{K}_{2} \mathrm{O}$ (NPK formulation 05-2020 ), with the crops being broadcasted sown. A dose of 40 $\mathrm{kg} \mathrm{ha}{ }^{-1}$ of $\mathrm{N}$ was applied in the form of urea on December 18, 2019.

The central area of a size of $6 \mathrm{~m} \times 6 \mathrm{~m}\left(36 \mathrm{~m}^{2}\right)$ at each uniformity trial, which had a size of $8 \mathrm{~m} \times 8 \mathrm{~m}$ $\left(64 \mathrm{~m}^{2}\right)$, was divided into 36 basic experimental units (BEU) of $1 \mathrm{~m} \times 1 \mathrm{~m}\left(1 \mathrm{~m}^{2}\right)$, forming a matrix of six rows and six columns. The plants were cut close to the soil surface between January 29 and February 4, 2020, at each BEU and weighed to determine the fresh matter (FM) productivity $\left(\mathrm{g} \mathrm{m}^{-2}\right)$ on a digital scale (accuracy of $1 \mathrm{~g}$ ). The pearl millet plants were at flowering and the slender leaf rattlebox and showy rattlebox plants did not reach the flowering stage at that time. The weighing was carried out immediately after cutting to minimize possible variations in plant moisture.

The FM data of the $36 \mathrm{BEU}$ allowed the planning of plots with adjacent $\mathrm{X}_{\mathrm{R}}$ BEU in the row and adjacent $\mathrm{X}_{\mathrm{C}} \mathrm{BEU}$ in the column for each uniformity trial. Plots with different sizes and/or shapes were planned as $\mathrm{X}=\mathrm{X}_{\mathrm{R}} \times \mathrm{X}_{\mathrm{C}}$, that is, $1 \times 1,1 \times 2,1 \times 3,1 \times 6,2 \times 1,2 \times 2,2 \times 3$, $2 \times 6,3 \times 1,3 \times 2,3 \times 3,3 \times 6,6 \times 1,6 \times 2$, and $6 \times 3$. The terms 
$\mathrm{X}_{\mathrm{R}}, \mathrm{X}_{\mathrm{C}}$, and $\mathrm{X}$ represent, respectively, the number of adjacent $\mathrm{BEU}$ in the row, the number of adjacent BEU in the column, and plot size in number of BEU. The number of plots (n) with an X BEU size $(n=36 / X)$ and the coefficient of variation $(\%)$ between plots of $\mathrm{X} \mathrm{BEU}$ in size $\left(\mathrm{CV}_{(\mathrm{X})}\right)$ were determined for each plot size $(\mathrm{X})$. The optimum plot size (Xo) was determined for each of the 27 trials using the methods modified maximum curvature (MMC) (MEIER; LESSMAN, 1971), linear response with plateau model (LRP) (PARANAÍBA; FERREIRA; MORAIS, 2009), and quadratic response with plateau model (QRP) (PEIXOTO; FARIA; MORAIS, 2011). Models of the dependent variable $\left(\mathrm{CV}_{(\mathrm{X})}, \%\right)$ as a function of the independent variable (X, BEU) are adjusted to these three methods.

The parameters $a$ and $b$ and the coefficient of determination $\left(\mathrm{R}^{2}\right)$ of the model $\mathrm{CV}_{(\mathrm{X})}=\mathrm{a} / \mathrm{X}^{\mathrm{b}}+\varepsilon$ were estimated for the modified maximum curvature (MMC) method (MEIER; LESSMAN, 1971). These parameters were estimated through a logarithmic transformation and linearization of $\mathrm{CV}_{(\mathrm{X})}=\mathrm{a} / \mathrm{X}^{\mathrm{b}}+\varepsilon$, that is, $\quad \log C V_{(X)}=\log a-b \log X+\varepsilon, \quad$ whose estimation was weighted by the degrees of freedom (DF $=\mathrm{n}-1$ ), associated with each plot size, according to the application of Sousa, Silva, and Assis (2016). The point corresponding to the optimum plot size (Xo) was determined algebraically using the expression $X o=\left[a^{2} b^{2}(2 b+1) /(b+2)\right]^{1 /(2 b+2)}$. The coefficient of variation corresponding to the optimum plot size $\left(C V_{X o}\right)$ was determined by $C V_{X o}=\mathrm{a} / X o^{\mathrm{b}}$.

Two segmented lines were adjusted for the linear response with plateau model (LRP) (PARANAÍBA; FERREIRA; MORAIS, 2009) and the estimations of the parameters $a, b$, and $p$ and the coefficient of determination $\left(\mathrm{R}^{2}\right)$ were obtained. The first line $\left(C V_{(X)}=a+b X+\varepsilon\right)$ is adjusted to the point corresponding to the optimum plot size (Xo), with a nonzero slope $(b)$. The second line $\left(C V_{(X)}=p+\varepsilon\right)$ starts from Xo and has a zero slope, that is, it is a line parallel to the abscissa, where $p$ is the plateau, i.e., $p$ corresponds to $\mathrm{CV}_{\mathrm{Xo}}$. The LRP model consisted of $C V_{(X)}= \begin{cases}a+b X+\varepsilon & \text { if } X \leq X o \\ p+\varepsilon & \text { if } X>X O\end{cases}$ size in the LRP model was $X_{O}=(p-a) / b$ and the coefficient of variation in the optimum plot size was determined by $C V_{\text {Xo }}=a+b X o$

The adjustment of the quadratic response with plateau model (QRP) (PEIXOTO; FARIA; MORAIS, 2011) was performed using two segmented equations. Estimations were obtained for the parameters $a, b, c$, and $p$ and the coefficient of determination $\left(\mathrm{R}^{2}\right)$. The quadratic part of the model $\left(C V_{(X)}=a+b X+c X^{2}+\varepsilon\right)$ was adjusted up to point Xo. The model becomes a straight line with a zero slope after Xo, being called a plateau, whose model is described by $\left(\mathrm{CV}_{(\mathrm{X})}=\mathrm{p}+\varepsilon\right)$, where $\mathrm{p}$ is the plateau, i.e., $\mathrm{p}=\mathrm{CV}_{\mathrm{Xo}}$. Thus, the QRP model $C V_{(X)}= \begin{cases}a+b X+c X^{2}+\varepsilon & \text { if } X \leq X o\end{cases}$ consisted of $C V_{(X)}= \begin{cases}a+b X+c X+\varepsilon & \text { if } X \leq X o \\ p+\varepsilon & \text { if } X>X o\end{cases}$ The optimum plot size in the QRP model was determined by $X o=-b / 2 c$ and the coefficient of variation in the optimum plot size was defined by $C V_{X o}=a-b^{2} / 4 c$. The point of union between the two segments in the LRP and QRP models corresponds to Xo in the abscissa and $\mathrm{CV}_{\mathrm{Xo}}$ in the ordinate. In the three models (MMC, LRP, and QRP), $\varepsilon$ is the residual or random error of the model.

Thus, the fresh matter productivity $\left(\mathrm{FM}, \mathrm{g} \mathrm{m}^{-2}\right.$ ) of the trial, the coefficient of variation of the trial $(\mathrm{CV}$, $\%$ ), and the estimates of the coefficient of determination $\left(\mathrm{R}^{2}\right)$, optimum plot size $(\mathrm{Xo})$, and coefficient of variation in the optimum plot size $\left(\mathrm{CV}_{\mathrm{Xo}}, \%\right)$ relative to the $\mathrm{MMC}$, LRP, and QRP methods were obtained for each of the three uniformity trials (replications) of each of the nine compositions. The data were subjected to analysis of variance and Scott-Knott test via bootstrap with 10,000 resamples at a $5 \%$ significance level to compare the compositions. These statistical procedures are adequate to circumvent possible impacts of not meeting the assumptions of normality of errors and homogeneity of residual variances (FERREIRA, 2014). Comparisons of the means of the $\mathrm{R}^{2}$, Xo, and $\mathrm{CV}_{\mathrm{Xo}}$ estimates between methods (MMC versus LRP, MMC versus QRP, and LRP versus QRP) were performed using the Student ttest (bilateral) for dependent samples at a 5\% significance level regardless of the composition $(n=27$ uniformity trials). The results of these comparisons were represented by letters next to the means. Statistical analyses were performed using the Microsoft Office Excel ${ }^{\circledR}$ application and the software R (R DEVELOPMENT CORE TEAM, 2020) and Sisvar (FERREIRA, 2014).

\section{RESULTS AND DISCUSSION}

The 27 uniformity trials, formed by sowing densities compositions of pearl millet (Pennisetum glaucum L.) of the cultivar BRS 1501 (M), slender leaf rattlebox (Crotalaria ochroleuca) of the common cultivar (CO), and showy rattlebox (Crotalaria spectabilis) (CS), showed a decrease in the coefficient of variation $\left(\mathrm{CV}_{(\mathrm{X})}\right)$ with an increase in the planned plot size (X) (Table 1). These results indicate an improvement in experimental precision (decrease in $\mathrm{CV}_{(\mathrm{X})}$ ) with an increase in plot size. Thus, although it is possible to evaluate the fresh matter productivity (FM) in $1-\mathrm{m}^{2}$ plots, as performed in this study, evaluating the precision at larger plot sizes is also important, that is, planning the experiment with the optimum plot size to ensure adequate discrimination of treatments under evaluation and reliability in inferences. It is also important to consider that smaller sizes may not represent plant development. 
Table 1. Planned plot size $\left(X=X_{R} \times X_{C}\right)$, in basic experimental units (BEU), with adjacent $X_{R} B E U$ in the row and adjacent $X_{C} B E U$ in the column, number of plots with $\mathrm{X} \mathrm{BEU}$ of size $(\mathrm{n}=36 / \mathrm{X})$, and coefficient of variation (\%) between plots with $\mathrm{X} \mathrm{BEU}$ of size $\left[\mathrm{CV} \mathrm{V}_{(\mathrm{X})}\right]$. Fresh matter productivity data from three uniformity trials (repetitions) of nine compositions of pearl millet (M), slender leaf rattlebox (CO), and showy rattlebox (CS).

\begin{tabular}{|c|c|c|c|c|c|c|c|c|c|c|c|c|c|}
\hline $\mathrm{T}^{(1)}$ & $X_{R}$ & $\mathrm{X}_{\mathrm{C}}$ & $X$ & $\mathrm{n}$ & $100 \% \mathrm{M}$ & $\begin{array}{l}75 \% \mathrm{M}+ \\
25 \% \mathrm{CO} \\
\end{array}$ & $\begin{array}{l}50 \% \mathrm{M}+ \\
50 \% \mathrm{CO} \\
\end{array}$ & $\begin{array}{l}25 \% \mathrm{M}+ \\
75 \% \mathrm{CO} \\
\end{array}$ & $100 \% \mathrm{CO}$ & $\begin{array}{l}75 \% \mathrm{M}+ \\
25 \% \mathrm{CS} \\
\end{array}$ & $\begin{array}{c}50 \% \mathrm{M}+ \\
50 \% \mathrm{CS} \\
\end{array}$ & $\begin{array}{c}25 \% \mathrm{M}+ \\
75 \% \mathrm{CS} \\
\end{array}$ & $100 \% \mathrm{CS}$ \\
\hline 1 & 1 & 1 & 1 & 36 & 12.14 & 11.08 & 14.85 & 15.44 & 17.67 & 15.89 & 18.51 & 13.27 & 17.07 \\
\hline 1 & 1 & 2 & 2 & 18 & 9.38 & 7.64 & 12.51 & 12.38 & 11.85 & 12.25 & 11.50 & 10.04 & 13.01 \\
\hline 1 & 1 & 3 & 3 & 12 & 6.23 & 6.54 & 11.28 & 10.58 & 10.95 & 8.75 & 7.55 & 8.51 & 11.77 \\
\hline 1 & 1 & 6 & 6 & 6 & 1.98 & 5.57 & 8.14 & 9.29 & 7.60 & 5.98 & 6.31 & 6.02 & 11.26 \\
\hline 1 & 2 & 1 & 2 & 18 & 10.17 & 7.15 & 10.10 & 10.84 & 13.51 & 10.47 & 11.30 & 8.55 & 12.76 \\
\hline 1 & 2 & 2 & 4 & 9 & 8.10 & 4.33 & 8.54 & 9.93 & 8.24 & 8.07 & 8.33 & 5.20 & 11.55 \\
\hline 1 & 2 & 3 & 6 & 6 & 4.91 & 2.30 & 6.10 & 9.02 & 8.63 & 5.51 & 5.61 & 4.76 & 10.68 \\
\hline 1 & 2 & 6 & 12 & 3 & 1.50 & 0.23 & 2.81 & 9.00 & 5.74 & 5.82 & 3.41 & 4.08 & 10.95 \\
\hline 1 & 3 & 1 & 3 & 12 & 7.62 & 5.88 & 9.19 & 10.25 & 12.27 & 8.91 & 9.57 & 5.95 & 12.30 \\
\hline 1 & 3 & 2 & 6 & 6 & 6.29 & 3.67 & 8.65 & 8.55 & 7.05 & 7.74 & 5.61 & 4.91 & 11.30 \\
\hline 1 & 3 & 3 & 9 & 4 & 4.77 & 1.08 & 7.53 & 8.37 & 7.37 & 4.50 & 4.64 & 3.88 & 11.57 \\
\hline 1 & 3 & 6 & 18 & 2 & 0.61 & 0.02 & 5.60 & 9.27 & 3.88 & 4.97 & 0.78 & 4.04 & 13.52 \\
\hline 1 & 6 & 1 & 6 & 6 & 7.48 & 5.72 & 8.21 & 6.06 & 9.49 & 6.29 & 5.21 & 3.16 & 4.30 \\
\hline 1 & 6 & 2 & 12 & 3 & 6.84 & 3.90 & 8.17 & 4.97 & 3.52 & 4.97 & 3.09 & 2.70 & 3.05 \\
\hline 1 & 6 & 3 & 18 & 2 & 5.69 & 0.40 & 7.08 & 4.37 & 8.11 & 1.30 & 5.06 & 2.06 & 1.66 \\
\hline 2 & 1 & 1 & 1 & 36 & 10.93 & 12.75 & 13.78 & 13.89 & 12.18 & 16.30 & 13.90 & 13.53 & 12.28 \\
\hline 2 & 1 & 2 & 2 & 18 & 8.18 & 6.25 & 9.98 & 9.83 & 7.49 & 12.38 & 9.66 & 9.26 & 8.74 \\
\hline 2 & 1 & 3 & 3 & 12 & 7.96 & 3.83 & 7.29 & 6.40 & 7.75 & 10.59 & 9.79 & 9.74 & 6.63 \\
\hline 2 & 1 & 6 & 6 & 6 & 5.12 & 2.92 & 5.67 & 5.54 & 3.65 & 8.41 & 6.83 & 6.34 & 1.74 \\
\hline 2 & 2 & 1 & 2 & 18 & 6.93 & 10.99 & 11.09 & 9.69 & 9.85 & 12.20 & 10.19 & 7.60 & 9.68 \\
\hline 2 & 2 & 2 & 4 & 9 & 5.21 & 5.34 & 8.41 & 8.36 & 4.97 & 9.69 & 8.04 & 5.72 & 6.29 \\
\hline 2 & 2 & 3 & 6 & 6 & 4.15 & 1.92 & 5.67 & 5.19 & 6.03 & 7.30 & 8.21 & 3.52 & 5.46 \\
\hline 2 & 2 & 6 & 12 & 3 & 1.68 & 1.30 & 3.78 & 4.95 & 3.08 & 3.35 & 4.73 & 2.84 & 1.18 \\
\hline 2 & 3 & 1 & 3 & 12 & 5.90 & 8.75 & 8.66 & 7.74 & 9.91 & 12.05 & 5.71 & 4.61 & 9.13 \\
\hline 2 & 3 & 2 & 6 & 6 & 3.93 & 4.03 & 7.63 & 7.00 & 5.59 & 9.54 & 4.77 & 3.89 & 6.12 \\
\hline 2 & 3 & 3 & 9 & 4 & 2.43 & 2.93 & 4.34 & 4.07 & 7.02 & 6.83 & 4.96 & 2.45 & 5.56 \\
\hline 2 & 3 & 6 & 18 & 2 & 1.84 & 3.11 & 5.27 & 3.53 & 2.86 & 1.42 & 2.30 & 2.78 & 1.50 \\
\hline 2 & 6 & 1 & 6 & 6 & 4.52 & 5.34 & 7.07 & 5.53 & 8.60 & 10.72 & 4.45 & 3.37 & 6.37 \\
\hline 2 & 6 & 2 & 12 & 3 & 1.43 & 2.30 & 6.95 & 5.81 & 1.22 & 9.43 & 4.14 & 2.98 & 4.88 \\
\hline 2 & 6 & 3 & 18 & 2 & 2.31 & 0.85 & 0.33 & 3.33 & 5.70 & 8.17 & 3.94 & 1.06 & 6.52 \\
\hline 3 & 1 & 1 & 1 & 36 & 14.68 & 12.89 & 16.52 & 17.84 & 14.38 & 12.26 & 15.14 & 17.76 & 9.87 \\
\hline 3 & 1 & 2 & 2 & 18 & 10.89 & 9.79 & 13.17 & 13.17 & 11.06 & 8.02 & 12.69 & 14.55 & 7.09 \\
\hline 3 & 1 & 3 & 3 & 12 & 8.81 & 7.10 & 11.52 & 11.61 & 9.63 & 7.17 & 11.21 & 8.56 & 4.96 \\
\hline 3 & 1 & 6 & 6 & 6 & 8.21 & 5.18 & 10.35 & 10.68 & 5.25 & 4.77 & 9.72 & 5.13 & 3.06 \\
\hline 3 & 2 & 1 & 2 & 18 & 11.71 & 8.48 & 11.06 & 11.46 & 8.54 & 8.02 & 12.44 & 12.48 & 7.82 \\
\hline 3 & 2 & 2 & 4 & 9 & 9.52 & 7.15 & 7.05 & 8.04 & 7.14 & 6.12 & 11.61 & 10.49 & 5.03 \\
\hline 3 & 2 & 3 & 6 & 6 & 8.47 & 4.22 & 6.30 & 6.57 & 4.81 & 4.49 & 10.42 & 5.61 & 3.89 \\
\hline 3 & 2 & 6 & 12 & 3 & 9.05 & 2.28 & 4.83 & 4.33 & 2.77 & 3.66 & 10.23 & 4.18 & 3.42 \\
\hline 3 & 3 & 1 & 3 & 12 & 8.39 & 8.04 & 9.17 & 7.83 & 4.67 & 6.11 & 9.39 & 7.63 & 6.55 \\
\hline 3 & 3 & 2 & 6 & 6 & 7.14 & 7.48 & 6.04 & 5.45 & 4.39 & 3.92 & 8.81 & 7.08 & 3.66 \\
\hline 3 & 3 & 3 & 9 & 4 & 5.68 & 2.35 & 5.65 & 4.57 & 1.49 & 3.91 & 7.11 & 3.28 & 2.86 \\
\hline 3 & 3 & 6 & 18 & 2 & 6.70 & 1.57 & 3.02 & 4.82 & 1.01 & 2.08 & 7.58 & 2.30 & 1.55 \\
\hline 3 & 6 & 1 & 6 & 6 & 5.53 & 5.15 & 6.05 & 6.03 & 2.31 & 4.95 & 7.01 & 5.12 & 5.64 \\
\hline 3 & 6 & 2 & 12 & 3 & 4.05 & 5.22 & 3.48 & 2.09 & 1.25 & 3.88 & 6.75 & 4.44 & 3.41 \\
\hline 3 & 6 & 3 & 18 & 2 & 1.37 & 1.43 & 4.08 & 0.62 & 1.20 & 3.88 & 2.15 & 3.13 & 1.00 \\
\hline
\end{tabular}

${ }^{(1)}$ Each uniformity trial with an area size of $6 \mathrm{~m} \times 6 \mathrm{~m}\left(36 \mathrm{~m}^{2}\right)$ was divided into 36 BEU of a size of $1 \mathrm{~m} \times 1 \mathrm{~m}\left(1 \mathrm{~m}^{2}\right)$, forming a matrix of six rows and six columns.

Fresh matter productivity (FM) varied from 4382 to $9077 \mathrm{~g} \mathrm{~m}^{-2}$, that is, 43.82 to $90.77 \mathrm{Mg} \mathrm{ha}^{-1}$, respectively (Table 2). The FM means from the three trials of each composition were $7325,7812,8466,8505$, 4511, 7442, 7861, 7955, and $4593 \mathrm{~g} \mathrm{~m}^{-2}$ for the compositions $100 \% \mathrm{M}, 75 \% \mathrm{M}+25 \% \mathrm{CO}, 50 \% \mathrm{M}+$ $50 \% \mathrm{CO}, 25 \% \mathrm{M}+75 \% \mathrm{CO}, 100 \% \mathrm{CO}, 75 \% \mathrm{M}+25 \%$ $\mathrm{CS}, 50 \% \mathrm{M}+50 \% \mathrm{CS}, 25 \% \mathrm{M}+75 \% \mathrm{CS}$, and $100 \%$
CS, respectively. Two groups of means were formed by the Scott-Knott test via bootstrap at a 5\% significance. The group with the highest FM production was formed by compositions of pearl millet cultivated alone and intercropped. The group with the lowest FM production was formed by slender leaf rattlebox and showy rattlebox cultivated alone. FM values of 34.59, 31.35, and 33.9 $\mathrm{Mg} \mathrm{ha}^{-1}$ were obtained by Passos et al. (2017), and 
5.327, 2.536, and $1.67 \mathrm{Mg} \mathrm{ha}^{-1}$ were obtained by Pfüller et al. (2019) for the same cultivars of pearl millet, slender leaf rattlebox, and showy rattlebox, respectively. In general, the values obtained in this study were higher than those reported in those studies and demonstrated good plant development at the experimental site.

Table 2. Fresh matter productivity (FM), coefficient of variation (CV), coefficient of determination $\left(\mathrm{R}^{2}\right)$, optimum plot size $\left(\mathrm{Xo}, \mathrm{m}^{2}\right)$, and coefficient of variation in the optimum plot size $\left(\mathrm{CV}_{\mathrm{Xo}}, \%\right)$ as a function of maximum modified curvature (MMC) methods, linear response with plateau (LRP) model, and quadratic response with plateau (QRP) model, in three uniformity trials (repetitions) of nine sowing density compositions of pearl millet (M), slender leaf rattlebox (CO), and showy rattlebox (CS). The F-test value and respective $\mathrm{p}$-value of the variance analysis via bootstrap with 10,000 resamples.

\begin{tabular}{|c|c|c|c|c|c|c|c|c|c|c|c|c|}
\hline \multirow[t]{2}{*}{ Composition } & \multirow[t]{2}{*}{ Trial $^{(1)}$} & \multirow[t]{2}{*}{$\mathrm{FM}, \mathrm{g} \mathrm{m}^{-2(2)}$} & \multirow[t]{2}{*}{$\mathrm{CV}, \%$} & \multicolumn{3}{|c|}{$\mathrm{MMC}$} & \multicolumn{3}{|c|}{ LRP } & \multicolumn{3}{|c|}{ QRP } \\
\hline & & & & $\mathrm{R}^{2}$ & $\mathrm{Xo}$ & $\mathrm{CV}_{\mathrm{X}_{0}}$ & $\mathrm{R}^{2}$ & $\mathrm{Xo}$ & $\mathrm{CV}_{\mathrm{Xo}_{0}}$ & $\mathrm{R}^{2}$ & Xo & $\mathrm{CV}_{\mathrm{X}_{0}}$ \\
\hline $100 \% \mathrm{M}$ & 1 & 7299 & 12.14 & 0.64 & 3.32 & 6.81 & 0.62 & 6.95 & 3.88 & 0.64 & 9.01 & 3.94 \\
\hline $100 \% \mathrm{M}$ & 2 & 7142 & 10.93 & 0.89 & 3.17 & 5.81 & 0.91 & 8.21 & 1.94 & 0.95 & 11.93 & 1.86 \\
\hline \multirow{2}{*}{$100 \% \mathrm{M}$} & 3 & 7534 & 14.68 & 0.79 & 3.27 & 9.02 & 0.65 & 7.51 & 5.37 & 0.67 & 9.97 & 5.43 \\
\hline & Average & $7325 \mathrm{a}$ & 12.58 & 0.77 & 3.25 & 7.21 & 0.73 & 7.56 & 3.73 & 0.75 & 10.31 & 3.74 \\
\hline $75 \% \mathrm{M}+25 \% \mathrm{CO}$ & 1 & 7349 & 11.08 & 0.63 & 3.67 & 4.18 & 0.80 & 8.78 & 1.13 & 0.82 & 12.64 & 1.05 \\
\hline $75 \% \mathrm{M}+25 \% \mathrm{CO}$ & 2 & 8042 & 12.75 & 0.78 & 3.61 & 5.08 & 0.75 & 6.73 & 2.10 & 0.74 & 8.09 & 2.27 \\
\hline \multirow[t]{2}{*}{$75 \% \mathrm{M}+25 \% \mathrm{CO}$} & 3 & 8044 & 12.89 & 0.86 & 3.45 & 6.69 & 0.84 & 8.38 & 2.57 & 0.84 & 11.56 & 2.60 \\
\hline & Average & $7812 \mathrm{a}$ & 12.24 & 0.76 & 3.58 & 5.32 & 0.80 & 7.97 & 1.93 & 0.80 & 10.76 & 1.97 \\
\hline $50 \% \mathrm{M}+$ & 1 & 8747 & 14.85 & 0.79 & 3.07 & 9.79 & 0.71 & 7.11 & 6.24 & 0.79 & 9.17 & 6.31 \\
\hline $50 \% \mathrm{M}+50 \% \mathrm{CO}$ & 2 & 8618 & 13.78 & 0.71 & 3.44 & 7.79 & 0.74 & 7.85 & 4.13 & 0.76 & 10.75 & 4.16 \\
\hline \multirow[t]{2}{*}{$50 \% \mathrm{M}+50 \% \mathrm{CO}$} & 3 & 8034 & 16.52 & 0.90 & 3.90 & 8.40 & 0.82 & 7.64 & 4.21 & 0.78 & 10.86 & 4.11 \\
\hline & Average & 8466 a & 15.05 & 0.80 & 3.47 & 8.66 & 0.76 & 7.53 & 4.86 & 0.77 & 10.26 & 4.86 \\
\hline $25 \% \mathrm{M}$ & 1 & 7843 & 15.44 & 0.83 & 2.93 & 10.56 & 0.66 & 6.73 & 7.19 & 0.77 & 8.09 & 7.31 \\
\hline $25 \% \mathrm{M}$ & 2 & & 13.89 & 0.91 & 3.24 & 7.75 & 0.80 & 6.99 & 4.34 & 0.87 & 5.83 & 5.05 \\
\hline \multirow{2}{*}{$25 \% \mathrm{M}+75 \% \mathrm{CO}$} & 3 & $90^{7}$ & 17.84 & 0.82 & 4.33 & 7.43 & 0.79 & 8.09 & 3.29 & 0.63 & 11.67 & 3.15 \\
\hline & Average & $8505 \mathrm{a}$ & 15.72 & 0.86 & 3.50 & 8.58 & 0.75 & 7.27 & 4.94 & 0.76 & 8.53 & 5.17 \\
\hline $100 \% \mathrm{CO}$ & 1 & & 17.67 & 0.90 & 3.83 & 9.65 & 0.80 & 7.34 & 5.72 & 0.78 & 10.07 & 5.70 \\
\hline $100^{\circ}$ & 2 & 4665 & 12.18 & 0.66 & 3.05 & 7.35 & 0.60 & 7.67 & 3.98 & 0.68 & 12.86 & 3.58 \\
\hline \multirow[t]{2}{*}{$100 \% \mathrm{CO}$} & 3 & 4413 & 14.38 & 0.84 & 4.01 & 5.21 & 0.85 & 7.44 & 1.54 & 0.79 & 9.98 & 1.61 \\
\hline & verag & $4511 \mathrm{~b}$ & 14.74 & 0.80 & 3.63 & 7.41 & 0.75 & 7.49 & 3.75 & 0.75 & 10.97 & 3.63 \\
\hline $75 \% \mathrm{M}$ & 1 & 93 & 15.89 & 0.91 & 3.78 & 8.00 & 0.83 & 7.12 & 4.31 & 0.83 & 8.93 & 4.47 \\
\hline $75 \% \mathrm{M}$ & 2 & 81 & 16.30 & 0.75 & 3.46 & 10.16 & 0.68 & 8.58 & 5.84 & 0.60 & 14.52 & 5.31 \\
\hline \multirow[t]{2}{*}{$75 \% \mathrm{M}+25 \% \mathrm{CS}$} & 3 & 51 & 12.26 & 0.96 & 3.09 & 6.62 & 0.86 & 6.65 & 3.48 & 0.94 & 5.93 & 3.98 \\
\hline & Averag & $7442 \mathrm{a}$ & 14.82 & 0.87 & 3.44 & 8.26 & 0.79 & 7.45 & 4.54 & 0.79 & 9.79 & 4.59 \\
\hline $50 \% \mathrm{M}+50 \% \mathrm{CS}$ & 1 & 8276 & 18.51 & 0.93 & 4.35 & 6.84 & 0.83 & 6.94 & 3.40 & 0.76 & 5.79 & 4.48 \\
\hline $50 \% \mathrm{M}+50 \% \mathrm{CS}$ & 2 & 7465 & 13.90 & 0.83 & 3.31 & 7.74 & 0.76 & 7.49 & 4.01 & 0.80 & 10.31 & 4.00 \\
\hline \multirow[t]{2}{*}{$50 \% \mathrm{M}+50 \% \mathrm{CS}$} & 3 & 7843 & 15.14 & 0.75 & 2.90 & 10.99 & 0.64 & 8.15 & 6.76 & 0.68 & 19.96 & 5.33 \\
\hline & Average & $7861 \mathrm{a}$ & 15.85 & 0.83 & 3.52 & 8.53 & 0.74 & 7.53 & 4.72 & 0.75 & 12.02 & 4.60 \\
\hline $25 \% \mathrm{M}-$ & 1 & 7827 & 13.27 & 0.90 & 3.46 & 6.51 & 0.82 & 6.65 & 3.35 & 0.89 & 5.77 & 3.96 \\
\hline $25 \% \mathrm{M}+75 \% \mathrm{CS}$ & 2 & 8234 & 13.53 & 0.85 & 3.60 & 5.76 & 0.78 & 7.08 & 2.42 & 0.79 & 8.90 & 2.55 \\
\hline \multirow[t]{2}{*}{$25 \% \mathrm{M}+75 \% \mathrm{CS}$} & 3 & 7804 & 17.76 & 0.91 & 4.36 & 7.28 & 0.87 & 6.96 & 3.47 & 0.80 & 8.82 & 3.62 \\
\hline & Average & $7955 \mathrm{a}$ & 14.85 & 0.89 & 3.81 & 6.52 & 0.83 & 6.90 & 3.08 & 0.83 & 7.83 & 3.38 \\
\hline $100 \%$ & 1 & 4382 & 17.07 & 0.54 & 3.41 & 11.00 & 0.35 & 6.90 & 8.15 & -0.08 & 8.79 & 8.22 \\
\hline $100 \% \mathrm{CS}$ & 2 & 4656 & 12.28 & 0.66 & 3.32 & 6.71 & 0.66 & 6.60 & 3.93 & 0.71 & 8.16 & 4.00 \\
\hline \multirow[t]{2}{*}{$100 \% \mathrm{CS}$} & 3 & 4742 & 9.87 & 0.89 & 2.85 & 5.87 & 0.83 & 7.44 & 2.45 & 0.91 & 10.05 & 2.47 \\
\hline & Average & $4593 \mathrm{~b}$ & 13.07 & 0.69 & 3.19 & 7.86 & 0.61 & 6.98 & 4.84 & 0.51 & 9.00 & 4.90 \\
\hline Overall & & 7163 & 14.33 & 0.81 & 3.49 & 7.59 & 0.75 & 7.41 & 4.04 & 0.75 & 9.94 & 4.09 \\
\hline & & 45.482 & 1.004 & 0.924 & 0.467 & 1.152 & 0.718 & 0.730 & 1.044 & 0.621 & 0.481 & 1.145 \\
\hline$p$-value ${ }^{(3)}$ & & 0.000 & 0.461 & 0.514 & 0.868 & 0.380 & 0.693 & 0.662 & 0.443 & 0.818 & 0.871 & 0.397 \\
\hline
\end{tabular}

\footnotetext{
(1) Each uniformity trial with an area size of $6 \mathrm{~m} \times 6 \mathrm{~m}\left(36 \mathrm{~m}^{2}\right)$ was divided into 36 BEU of a size of $1 \mathrm{~m} \times 1 \mathrm{~m}\left(1 \mathrm{~m}^{2}\right)$, forming a matrix of six rows and six columns. ${ }^{(2)}$ Averages that are not followed by the same letter in the column (comparison of averages of the compositions) differ at $5 \%$ significance by the Scott Knott's test via bootstrap with 10,000 resamples. ${ }^{(3)} p$-value $>0.05$ means that averages of the compositions do not differ.
}

The CV of FM obtained among the $36 \mathrm{BEU}$ of each of the 27 uniformity trials varied from 9.87 to $18.51 \%$, with a mean of $14.33 \%$ (Table 2). The CV means of the three trials of each composition were 12.58, $12.24,15.05,15.72,14.74,14.82,15.85,14.85$, and
$13.07 \%$ for the compositions $100 \% \mathrm{M}, 75 \% \mathrm{M}+25 \%$ $\mathrm{CO}, 50 \% \mathrm{M}+50 \% \mathrm{CO}, 25 \% \mathrm{M}+75 \% \mathrm{CO}, 100 \% \mathrm{CO}$, $75 \% \mathrm{M}+25 \% \mathrm{CS}, 50 \% \mathrm{M}+50 \% \mathrm{CS}, 25 \% \mathrm{M}+75 \%$ CS, and $100 \%$ CS, respectively. The F-test of the analysis of variance showed that the $\mathrm{CV}$ values did not 
differ from each other $(\mathrm{p}$-value $=0.461)$, revealing similar experimental precision between compositions. It suggests that the plot size in experiments with pearl millet, slender leaf rattlebox, and showy rattlebox cultivated alone or intercropped may be similar.

The means of the coefficient of determination $\left(\mathrm{R}^{2}\right)$, optimum plot size (Xo), and coefficient of variation in the optimum plot size $\left(\mathrm{CV}_{\mathrm{Xo}}\right)$ did not differ between the nine compositions of sowing densities of pearl millet, slender leaf rattlebox, and showy rattlebox for the methods modified maximum curvature (MMC), linear response with plateau model (LRP), and quadratic response with plateau model (QRP) (Tables 2 and 3). Therefore, based on this finding and the lack of difference in the coefficient of variation of trials between compositions, the experimental planning regarding the plot size is similar for these crops cultivated alone or intercropped.

Table 3. Averages of coefficients of determination $\left(\mathrm{R}^{2}\right)$, optimum plot size $\left(\mathrm{Xo}, \mathrm{m}^{2}\right)$, and coefficient of variation in the optimum plot size $\left(\mathrm{CV}_{\mathrm{Xo}}, \%\right)$ as a function of maximum modified curvature (MMC) methods, linear response with plateau (LRP) model, and quadratic response with plateau (QRP) model obtained from fresh matter productivity in three uniformity trials (repetitions) of nine compositions of pearl millet (M), slender leaf rattlebox (CO), and showy rattlebox (CS).

\begin{tabular}{|c|c|c|c|}
\hline Composition & $\mathrm{MMC}$ & LRP & QRP \\
\hline \multicolumn{4}{|c|}{ Coefficient of determination $\left(\mathrm{R}^{2}\right)$} \\
\hline $100 \% \mathrm{M}$ & $0.77 \mathrm{a}$ & $0.73 \mathrm{a}$ & $0.75 \mathrm{a}$ \\
\hline $75 \% \mathrm{M}+25 \% \mathrm{CO}$ & $0.76 \mathrm{a}$ & $0.80 \mathrm{a}$ & $0.80 \mathrm{a}$ \\
\hline $50 \% \mathrm{M}+50 \% \mathrm{CO}$ & $0.80 \mathrm{a}$ & $0.76 \mathrm{a}$ & $0.77 \mathrm{a}$ \\
\hline $25 \% \mathrm{M}+75 \% \mathrm{CO}$ & $0.86 \mathrm{a}$ & $0.75 \mathrm{a}$ & $0.76 \mathrm{a}$ \\
\hline $100 \% \mathrm{CO}$ & $0.80 \mathrm{a}$ & $0.75 \mathrm{a}$ & $0.75 \mathrm{a}$ \\
\hline $75 \% \mathrm{M}+25 \% \mathrm{CS}$ & $0.87 \mathrm{a}$ & $0.79 \mathrm{a}$ & $0.79 \mathrm{a}$ \\
\hline $50 \% \mathrm{M}+50 \% \mathrm{CS}$ & $0.83 \mathrm{a}$ & $0.74 \mathrm{a}$ & $0.75 \mathrm{a}$ \\
\hline $25 \% \mathrm{M}+75 \% \mathrm{CS}$ & $0.89 \mathrm{a}$ & $0.83 \mathrm{a}$ & $0.83 \mathrm{a}$ \\
\hline $100 \% \mathrm{CS}$ & $0.69 \mathrm{a}$ & $0.61 \mathrm{a}$ & $0.51 \mathrm{a}$ \\
\hline Overall average & $0.81 \mathrm{~A}$ & $0.75 \mathrm{~B}$ & $0.75 \mathrm{~B}$ \\
\hline \multicolumn{4}{|c|}{ Optimum plot size $\left(\mathrm{Xo}, \mathrm{m}^{2}\right)$} \\
\hline $100 \% \mathrm{M}$ & $3.25 \mathrm{a}$ & $7.56 \mathrm{a}$ & $10.31 \mathrm{a}$ \\
\hline $75 \% \mathrm{M}+25 \% \mathrm{CO}$ & $3.58 \mathrm{a}$ & $7.97 \mathrm{a}$ & $10.76 \mathrm{a}$ \\
\hline $50 \% \mathrm{M}+50 \% \mathrm{CO}$ & $3.47 \mathrm{a}$ & $7.53 \mathrm{a}$ & $10.26 \mathrm{a}$ \\
\hline $25 \% \mathrm{M}+75 \% \mathrm{CO}$ & $3.50 \mathrm{a}$ & $7.27 \mathrm{a}$ & $8.53 \mathrm{a}$ \\
\hline $100 \% \mathrm{CO}$ & $3.63 \mathrm{a}$ & $7.49 \mathrm{a}$ & $10.97 \mathrm{a}$ \\
\hline $75 \% \mathrm{M}+25 \% \mathrm{CS}$ & $3.44 \mathrm{a}$ & $7.45 \mathrm{a}$ & $9.79 \mathrm{a}$ \\
\hline $50 \% \mathrm{M}+50 \% \mathrm{CS}$ & $3.52 \mathrm{a}$ & $7.53 \mathrm{a}$ & $12.02 \mathrm{a}$ \\
\hline $25 \% \mathrm{M}+75 \% \mathrm{CS}$ & $3.81 \mathrm{a}$ & $6.90 \mathrm{a}$ & $7.83 \mathrm{a}$ \\
\hline $100 \% \mathrm{CS}$ & $3.19 \mathrm{a}$ & $6.98 \mathrm{a}$ & $9.00 \mathrm{a}$ \\
\hline Overall average & $3.49 \mathrm{C}$ & $7.41 \mathrm{~B}$ & $9.94 \mathrm{~A}$ \\
\hline \multicolumn{4}{|c|}{ Coefficient of variation in the optimum plot size $\left(\mathrm{CV}_{\mathrm{Xo}}, \%\right)$} \\
\hline $100 \% \mathrm{M}$ & $7.21 \mathrm{a}$ & $3.73 \mathrm{a}$ & $3.74 \mathrm{a}$ \\
\hline $75 \% \mathrm{M}+25 \% \mathrm{CO}$ & $5.32 \mathrm{a}$ & $1.93 \mathrm{a}$ & $1.97 \mathrm{a}$ \\
\hline $50 \% \mathrm{M}+50 \% \mathrm{CO}$ & $8.66 \mathrm{a}$ & $4.86 \mathrm{a}$ & $4.86 \mathrm{a}$ \\
\hline $25 \% \mathrm{M}+75 \% \mathrm{CO}$ & $8.58 \mathrm{a}$ & $4.94 \mathrm{a}$ & $5.17 \mathrm{a}$ \\
\hline $100 \% \mathrm{CO}$ & $7.41 \mathrm{a}$ & $3.75 \mathrm{a}$ & $3.63 \mathrm{a}$ \\
\hline $75 \% \mathrm{M}+25 \% \mathrm{CS}$ & $8.26 \mathrm{a}$ & $4.54 \mathrm{a}$ & $4.59 \mathrm{a}$ \\
\hline $50 \% \mathrm{M}+50 \% \mathrm{CS}$ & $8.53 \mathrm{a}$ & $4.72 \mathrm{a}$ & $4.60 \mathrm{a}$ \\
\hline $25 \% \mathrm{M}+75 \% \mathrm{CS}$ & $6.52 \mathrm{a}$ & $3.08 \mathrm{a}$ & $3.38 \mathrm{a}$ \\
\hline $100 \% \mathrm{CS}$ & $7.86 \mathrm{a}$ & $4.84 \mathrm{a}$ & $4.90 \mathrm{a}$ \\
\hline Overall average & $7.59 \mathrm{~A}$ & $4.04 \mathrm{~B}$ & $4.09 \mathrm{~B}$ \\
\hline
\end{tabular}

*Averages of $\mathrm{R}^{2}, \mathrm{Xo}$, and $\mathrm{CV}_{\mathrm{Xo}}$ that are not followed by the same lowercase letter in the column (comparison of compositions within each method) differ at 5\% significance by the Scott Knott's test. Averages that are not followed by the same uppercase letter in the row (comparison of methods regardless of composition, $\mathrm{n}=27$ uniformity trials) differ by the $t$-test of Student (bilateral) at $5 \%$ de significance.

The means of the coefficient of determination $\left(\mathrm{R}^{2}\right)$ did not differ between the nine compositions, varying from 0.69 to $0.89,0.61$ to 0.83 , and 0.51 to 0.83 for the MMC, LRP, and QRP methods, respectively (Table 3), considering that $0.00 \leq \mathrm{R}^{2} \leq 1.00$ and that the closer to 1.00 , the better the model fits the data. In general, the $\mathrm{R}^{2}$ values of the MMC method were higher than the values of the LRP and QRP methods within each composition. The comparison of methods showed that the $\mathrm{R}^{2}$ value of MCC $(0.81)$ was higher and those of LRP (0.75) and QRP (0.75) did not differ from each other, regardless of the composition of sowing densities 
of $\mathrm{M}, \mathrm{CO}$, and $\mathrm{CS}$. Thus, all methods presented $\mathrm{R}^{2}$ values close to the unit $\left(\mathrm{R}^{2} \geq 0.75\right)$ although the adjustments were differentiated.

The means of the optimum plot size (Xo) did not differ between the nine compositions and, in general, they were higher in the QRP method $\left(7.83 \leq \mathrm{Xo} \leq 12.02 \mathrm{~m}^{2}\right)$, intermediate in the LRP method $\left(6.90 \leq X_{0} \leq 7.97 \mathrm{~m}^{2}\right)$, and lower in the MMC method $\left(3.19 \leq X_{0} \leq 3.81 \mathrm{~m}^{2}\right)$. Xo differed between the three methods regardless of composition, with $9.94 \mathrm{~m}^{2}$ for QRP, $7.41 \mathrm{~m}^{2}$ for LRP, and $3.49 \mathrm{~m}^{2}$ for MMC. Thus, the plot size may be the same for these compositions and depends on the estimation method.

The coefficients of variation in the optimum plot size $\left(\mathrm{CV}_{\mathrm{Xo}}, \%\right)$ did not differ between the nine compositions and ranged from 5.32 to $8.66 \%, 1.93$ to $4.94 \%$, and 1.97 to $5.17 \%$ for the MMC, LRP, and QRP methods, respectively (Table 3 ). In general, the $R^{2}$ values of MMC were higher and the $\mathrm{R}^{2}$ values of LRP and QRP were similar to each other within each composition. The comparisons of methods showed that the $\mathrm{CV}_{\mathrm{Xo}}$ of $\mathrm{MMC}$ (7.59\%) was higher and the LRP (4.04\%) and QRP methods $(4.09 \%)$ did not differ from each other regardless of the composition. These results indicate better experimental precision with the use of the plot sizes determined by the LRP and QRP methods compared to $\mathrm{MMC}$, regardless of the composition.

In general, the mean of $\mathrm{R}^{2}$ was higher in MMC (0.81), with no difference between LRP $(0.75)$ and QRP (0.75), regardless of the composition. The means of Xo presented decreasing values in the following order: $\mathrm{QRP}$ $=9.94 \mathrm{~m}^{2}, \mathrm{LRP}=7.41 \mathrm{~m}^{2}$, and $\mathrm{MMC}=3.49 \mathrm{~m}^{2} . \mathrm{CV}_{\mathrm{Xo}}$ was higher in MMC $(7.59 \%)$ and no difference was found between LRP (4.04\%) and QRP (4.09\%). Thus, the plot sizes were different between the LRP $\left(7.41 \mathrm{~m}^{2}\right)$ and QRP methods $\left(9.94 \mathrm{~m}^{2}\right)$ but resulted in a similar experimental precision because the $\mathrm{CV}_{\mathrm{Xo}}$ values did not differ. This lack of difference occurred because the gains in precision (decrease in $\mathrm{CV}_{\mathrm{X}_{0}}$ ) with the addition of the plot area are not significant after a certain plot size. Thus, plots with an area of $7.41 \mathrm{~m}^{2}$ are suitable for experimental planning. This indication of plots of $7.41 \mathrm{~m}^{2}$ is supported by practical feasibility in the field and stabilization of precision from that size, being used as a reference for planning experiments with pearl millet, slender leaf rattlebox, and showy rattlebox cultivated alone or intercropped.

This plot size of $7.41 \mathrm{~m}^{2}$ is relatively larger than the plot size determined to evaluate the fresh matter productivity of the common cultivar of pearl millet, which reached $4.46 \mathrm{~m}^{2}$ in three evaluation periods (BURIN et al., 2015) and $4.97 \mathrm{~m}^{2}$ for the three sowing and cutting seasons (BURIN et al., 2016). It was also larger than the sizes of $2.04 \mathrm{~m}^{2}$ (FACCO et al., 2017) and $1.98 \mathrm{~m}^{2}$ (FACCO et al., 2018) to evaluate the fresh matter productivity of sunn hemp. The differences between environments, pearl millet cultivars, rattlebox species, and the methodologies used to determine the plot size contributed to explaining the different results compared to those obtained in this study. Additionally, this plot size of $7.41 \mathrm{~m}^{2}$ is smaller than those used in conventional studies of Debiasi et al. (2016), Passos et al. (2017), Sousa et al. (2017), Ferreira et al. (2019), Pfüller et al. (2019), and Ascari et al. (2020), as well as in studies with pearl millet, slender leaf rattlebox, and showy rattlebox, along with other soil cover species.

Higher estimates of $\mathrm{R}^{2}$ and $\mathrm{CV}_{\mathrm{Xo}}$ and lower of Xo were obtained with the MMC method compared to LRP in rice (PARANAÍBA; FERREIRA; MORAIS, 2009), wheat, cassava (PARANAÍBA; MORAIS; FERREIRA, 2009), and papaya (BRITO et al., 2012). In passion fruit, higher $\mathrm{R}^{2}$ and $\mathrm{Xo}$ values and lower $\mathrm{CV}_{\mathrm{Xo}}$ values were obtained with the QRP method compared to LRP (PEIXOTO; FARIA; MORAIS, 2011). Therefore, in general, these studies with the approach of comparing methods to determine the optimum plot size showed results similar to those of the present study.

\section{CONCLUSIONS}

The optimum plot size differs between methods and decreases in the following order: quadratic response with plateau model $\left(9.94 \mathrm{~m}^{2}\right)$, linear response with plateau model $\left(7.41 \mathrm{~m}^{2}\right)$, and modified maximum curvature $\left(3.49 \mathrm{~m}^{2}\right)$. The optimum plot size to evaluate the fresh matter productivity of pearl millet, slender leaf rattlebox, and showy rattlebox cultivated alone or intercropped is $7.41 \mathrm{~m}^{2}$. This size could be used as a reference for future experiments.

\section{ACKNOWLEDGEMENTS}

To the National Council for Scientific and Technological Development (CNPq - Processes 401045/2016-1 and 304652/2017-2); to the Coordination for Improvement of Higher Education Personnel (CAPES), for granting scholarships to the authors; to the Research Support Foundation of the State of Rio Grande do Sul (FAPERGS), for the scientific initiation scholarship; and to the scholarship holder students and volunteers for their assistance in data collection.

\section{REFERENCES}

ALVARES, C. A. et al. Köppen's climate classification map for Brazil. Meteorologische Zeitschrift, 22: 711728, 2013.

ASCARI, J. P. et al. Influence of biological fertilizer and plant cover in the physical properties of soil. Revista Agrarian, 13: 42-55, 2020.

BRITO, M. C. M. et al. Estimação do tamanho ótimo de parcela via regressão antitônica. Revista Brasileira de Biometria, 30: 353-366, 2012.

BURIN, C. et al. Plot size and number of replicates in 
times of sowing and cuts of millet. Revista Brasileira de Engenharia Agrícola e Ambiental, 20: 119-127, 2016.

BURIN, C. et al. Tamanho de parcela e número de repetições na cultura do milheto em épocas de avaliação. Bragantia, 74: 261-269, 2015.

DEBIASI, H. et al. Práticas culturais na entressafra da soja para o controle de Pratylenchusbrachyurus. Pesquisa Agropecuária Brasileira, 51: 1720-1728, 2016.

FACCO, G. et al. Basic experimental unit and plot sizes for fresh matter of sunn hemp. Ciência Rural, 48: e20170660, 2018.

FACCO, G. et al. Basic experimental unit and plot sizes with the method of maximum curvature of the coefficient of variation in sunn hemp. African Journal of Agricultural Research, 12: 415-423, 2017.

FERREIRA, D.F. Sisvar: a guide for its bootstrap procedures in multiple comparisons. Ciência e Agrotecnologia, 38: 109-112, 2014.

FERREIRA, N. M. et al. Potential of species of green coverage in Entisol. Journal of Agricultural Science, 11: 263-273, 2019.

GUIMARÃES, B. V. C. et al. Methods for estimating optimum plot size for 'Gigante' cactus pear. Journal of Agricultural Science, 11: 205-211, 2019.

MEIER, V. D.; LESSMAN, K. J. Estimation of optimum field plot shape and size for testing yield in Crambeabyssinica Hochst. Crop Science, 11: 648-650, 1971.

PARANAÍBA, P. F.; FERREIRA, D. F.; MORAIS, A. R. Tamanho ótimo de parcelas experimentais: proposição de métodos de estimação. Revista Brasileira de Biometria, 27: 255-268, 2009.

PARANAÍBA, P. F.; MORAIS, A. R.; FERREIRA, D. F. Tamanho ótimo de parcelas experimentais: comparação de métodos em experimentos de trigo e mandioca. Revista Brasileira de Biometria, 27: 81-90, 2009.

PASSOS, A. M. A. et al. Effect of cover crops on physico-chemical attributes of soil in a short-term experiment in the southwestern Amazon region. African Journal of Agricultural Research, 12: 3339-3347, 2017.

PEIXOTO, A. P. B.; FARIA, G. A.; MORAIS, A. R. Modelos de regressão com platô na estimativa do tamanho de parcelas em experimento de conservação in vitro de maracujazeiro. Ciência Rural, 41: 1907-1913, 2011.

PFÜLLER, E. E. et al. Aspectos fenológicos e produtividade de espécies de verão para cobertura de solo em Vacaria, RS. Investigación Agraria, 21: 23-30, 2019.

R Development Core Team. R: A Language and Environment for Statistical Computing. Vienna: R Foundation for Statistical Computing. 2020.

SANTOS, H. G. et al. Sistema Brasileiro de Classificação de Solos. 5. ed. Brasília, DF: Embrapa, 2018. $356 \mathrm{p}$.

SOUSA, D. C. et al. Chemical attributes of agricultural soil after the cultivation of cover crops. Australian Journal of Crop Science, 11: 1497-1503, 2017.

SOUSA, R. P.; SILVA, P. S. L.; ASSIS, J. P. Tamanho e forma de parcelas para experimentos com girassol. Revista Ciência Agronômica, 47: 683-690, 2016. 